\title{
PONDOK PESANTREN DI PROVINSI BENGKULU DALAM DINAMIKA PERADABAN MODEREN
}

\author{
Qolbi Khoiri', Abdullah Idi², Akmal Hawi \\ 1,2,3 Program Pascasarjana (S3) UIN Raden Fatah Palembang \\ J. Prof. K. H. Zainal Abidin Fikri, Telp. (0711) 353276 Palembang \\ E-mail: qolbikhoiri@gmail.com
}

\begin{abstract}
Pondok Pesantren in Bengkulu Province in the Dynamics of Modern Civilization. This paper aims to determine what the potential of pondok pesantren in Bengkulu Province is and how its strategy is in order to face the values of modern civilization. The research method used is qualitative research method with the type of descriptive-analytic research and with data sources are the leaders and caregivers of boarding schools in Bengkulu Province. According to his approach, this study uses sociological and phenomenological approaches. The results showed that pondok pesantren in Bengkulu Province has potential that is divided into several things, firstly the potential of the majority Muslim community, the internal potential in the form of tradition of pesantren consisting of kiai, santri, pondok, masjid and kitab kuning, then the potential of science development and technology based on tauhid and the last economic potential through the development of charity business pondok pesantren of various sectors in order to grow the independence of institutions, independence of managers and independence of students in the face of the values of modern civilization. The strategy of boarding school in facing the values of modern civilization can be seen from the strengths, opportunities, weaknesses and threats (SWOT). This paper mentioned that the strategy undertaken by boarding school in Bengkulu Province is modernization in education management, including on administration, organization, educators and education, supervision and evaluation.
\end{abstract}

Keywords: strategy; pondok pesantren; values of modern civilization.

\begin{abstract}
Abstrak: Pondok Pesantren di Provinsi Bengkulu dalam Dinamika Peradaban Modern.Tulisan ini bertujuan untuk mengetahui apa potensi yang dimiliki pondok pesantren di Provinsi Bengkulu dalam rangka menghadapi nilai-nilai peradaban modern dan bagaimana strateginya. Metode penelitian yang digunakan adalah metode penelitian kualitatif dengan jenis penelitian deskriptif analisis dengan sumber data penelitian adalah pimpinan dan pengasuh pondok pesantren yang ada di Provinsi Bengkulu. Menurut pendekatannya, penelitian ini menggunakan pendekatan sosiologis dan fenomenologis. Hasil penelitian menunjukkan bahwa pondok pesantren di Provinsi Bengkulu memiliki potensi yang terbagi pada beberapa hal, pertama potensi masyarakat yang mayoritas muslim, potensi internal dalam bentuk tradisi pesantren yang terdiri dari kiai, santri, pondok, masjid dan kitab kuning, kemudian potensi pengembangan ilmu pengetahuan dan teknologi berbasis tauhid serta yang terakhir potensi ekonomi melalui pengembangan amal usaha pondok pesantren dari berbagai sektor guna menumbuhkan kemandirian lembaga, kemandirian pengelola dan kemandirian santri dalam menghadapi nilai-nilai peradaban modern. Strategi pondok pesantren dalam menghadapi nilai-nilai peradaban modern dapat di lihat dari kekuatan, peluang, kelemahan dan ancaman (SWOT). Dalam tulisan ini disebutkan bahwa strategi yang dilakukan pondok pesantren di Provinsi Bengkulu adalah dengan cara modernisasi manajemen pengelolalan pendidikan, termasuk mengenai administrasi, organisasi, tenaga pendidik dan kependidikan, supervisi dan evaluasi.
\end{abstract}

Kata kunci: strategi; pondok pesantren; nilai-nilai peradaban modern.

\section{Pendahuluan}

Pesantren merupakan salah satu lembaga pendidikan Islam di Indonesia yang perkembangannya hingga akhir abad ke-19 me- ngalami peningkatan yang cukup besar, ${ }^{1}$ yaitu

1 Pada tahun 2011, Kepala Pusat Pusat Pengembangan Penelitian dan Pendidikan Pelatihan Kementerian Agama H. Abdul Jamil mengatakan bahwa jumlah santri pondok 
adanya proses transmisi Islam dalam kebudayaan agama lain. Itulah yang kemudian menjadikannya berkembang di Indonesia; dengan ciri khas dan karakter yang melekat pada setiap pesantren yang tumbuh dan berkembang tersebut. Sebagai sebuah tempat penyebaran Islam sekaligus institusi pendidikan Islam tertua di Indonesia, pesantren ${ }^{2}$ memiliki banyak sekali tradisi dan potensi nilainilai keadaban. Sejak awal, kemunculannya hingga sekarang, pesantren memiliki arti dan peran yang sangat penting di tengah-tengah masyarakat. Hingga, tidak sedikit kalangan pengkaji Islam Indonesia menyebut pesantren sebagai kampung peradaban, artefak peradaban Indonesia, sub-

pesantren di 33 provinsi di seluruh Indonesia mencapai 3,65 juta yang tersebar di 25.000 pondok pesantren. "Jumlah tersebut terus bertambahnya setiap tahunnya. Ini merupakan sebuah kemajuan yang patut dibanggakan," katanya seusai pembukaan Musabaqah Fahmi Kubtubit Turats (Mufakat) di Pondok Pesantren (Ponpes) Nahdlatul Wathan Poncor, Lombok Timur, Selasa (19/7). Lihat. Khazanah Republika tahun 2011. Pada tahun 2012 data pesantren meningkat menjadi 27.230 buah. Lihat. http://ditpdpontren.kemenag. go.id/tag/bank-indonesia/. Diakses tanggal 25 Desember 2016. Dari total 49.337 Madrasah (tidak termasuk RA) yang ada di Indonesia, sebagian besar, sekitar 92,1\% (45.451) adalah madrasah swasta. Dan hanya 7,9 \% (3.886) saja yang merupakan Madrasah Negeri.Sementara jumlah Madarasah untuk masing-masing jenjang, jumlahnya adalah sebagai berikut; Madrasah Ibtidaiyah Negeri sejumlah 1.686, Madrasah Ibtidaiyah Swasta sejumlah 22.874; Madrasah Tsanawiyah Negeri sejumlah 1.437; Madrasah Tsanawiyah Swasta sejumlah 15.497; Madrasah Aliyah Negeri sejumlah 763; Madrasah Aliyah Swasta sejumlah 7.080. lihat. Data EMIS Pendis Kemenag, hingga Semester Genap 2015/2016.

2 Berdasarkan analisis penulis, ada tiga pendapat yang paling masyhur, Pertama; Pigeout dan Fokkens, menurut kedua tokoh ini, Pesantren adalah komunitas yang tempatnya berada jauh di pegunungan dan berasal dari lembaga sejenis zaman pra Islam semacam Mandala dan Asrama, demikian juga Fokkens yang menyatakan bahwa pesantren berasal dari tanah peradikan, jenis tanah bebas di mana pada zaman pra-islam didalamnya terdapat mandala dan asrama yang disebut dengan putihan atau mutihan; Kedua, Bruinessen menyatakan bahwa ia meragukan pendapat pertama, sebab menurutnya pesantren diadopsi dari lembaga pendidikan Islam Timur Tengah, sehingga ia menduga pesantren di Indonesia merupakan model lembaga pendidikan Islam di Timur Tengah yang berkembang di Indonesia sejak awal Abad 18 dan terlembaga pada awal abad 19; Ketiga; meski sedikit hampir sama dengan Bruinessen, namun Dhofier lebih tegas menyatakan bahwa pesantren sudah ada di Indonesia sejak awal-awal penyebaran Islam (inilah substansi perbedaan dengan Bruinessen, meski sama-sama sepakat dari lembaga pendidikan Islam, namun menurut Bruinessen baru ada lembaga pesantren sejak awal abad 19). Lebih lanjut dapat ditelusuri dalam Hanun Asrohah, Pelembagaan Pesantren; Asal-usul dan Perkembangan Pesantren di Jawa, (Jakarta: Departemen Agama RI Bagian Proyek Peningkatan Informasi Penelitian dan Diklat Keagamaan, 2004), h. 1-6 kultur, institusi kultural, dan lain-lain. Mencermati fungsi pokok pendidikan dalam peradaban masyarakat modern, sesungguhnya lembaga pendidikan di pesantren haruslah mengambil peran yang jelas dalam rangka membangun peradaban modern.

Fenomena yang dirasakan pondok pesantren-khususnya di Provinsi Bengkulu sebagai implikasi dari peradaban modernadalah terjadinya pergeseran makna pendidikan pesantren bagi masyarakat. Secara sosiologis, hal tersebut digambarkan dengan keadaan di mana suatu masyarakat dalam konteks perubahan termasuk pendidikan, ada kecendrungan berpikir rate of return (nilai imbalan). Kecendrungan ini terjadi disebabkan pendidikan dipandang sebagai bentuk investasi, baik modal maupun manusia (human capital and capital investment) untuk membantu meningkatkan keterampilan dan pengetahuan sekaligus mempunyai kemampuan produktif di masa depan yang diukur dari tingkat penghasilan yang diperolehnya. Artinya, perubahan yang terjadi di dalam masyarakat dalam bidang yang lain memengaruhi pula pandangan dan pilihan masyarakat terhadap pendidikan.

Selanjutnya juga dialami oleh memudarnya watak kemandirian yang menjadi ciri khas pesantren dan sebagai pembeda dengan lembaga-lembaga pendidikan lainnya. Ini terjadi karena tuntutan modernitas dari sisi kebijakan pendidikan nasional dan juga untuk merespon paradigm rate of return, yaitu pendidikan merupakan investasi masa depan dan juga modal masa depan tersebut. Hal yang paling kentara tampak adalah pendirian pendidikan formal (madrasah/sekolah). Dari seluruh pesantren yang ada di Provinsi Bengkulu, hanya empat pesantren yang tidak mendirikan pendidikan formal. Hal ini tentunya juga berakibat pada mengendurnya tradisi, kurikulum, pola/sistem pembelajaran pesantren sehingga fokus utama pengembangan adalah sekolah formalnya. Ini juga terkait dengan layak atau tidaknya para alumni pesantren dalam kompetisi peluang kerja. Fenomena ini di satu isi merupakan respons positif karena berhasil memadukan pendidikan modern ke dalamnya,tetapi di sisi 
lain, perkembangan ini sangat mengkhawatirkan fungsi akademik pesantren sebagai pencetak ulama dan ahli-ahli agama yang unggul. ${ }^{3}$

Kondisi pesantren di Provinsi Bengkulu saat ini juga mengalami pergeseran dari kepemimpinan. Di pesantren, kepemimpinan seorang kiai sebagaimana yang telah digambarkan Ziemek ${ }^{4}$ adalah kepemimpinan karismatik yang mempunyai kewenangan penuh untuk mengelola pesantren yang didirikannya. Kiai berperan sebagai perencana, pelaksana, dan pengevaluasi terhadap semua kegiatan yang dilaksanakan di pondok pesantren. Pada sistem yang seperti ini, kiai memegang pimpinan mutlak dalam segala hal. Secara sosiologis, peran dan fungsi kepemimpinan kiai sangatlah penting. la memiliki kedudukan kultural dan struktural yang tinggi di mata masyarakatnya. Realitas ini memungkinkan kiai berkontribusi besar terhadap aneka problem keumatan. Peran kepemimpinan kiai tidak hanya terbatas pada aspek spiritual, namun juga aspek kehidupan sosial yang lebih luas. 5

Berdasarkan hal tersebut, maka penelitian ini menjadi penting untuk menganalisis mengenai pondok pesantren dan peradaban modern, dengan fokus bahasan mengenai dinamika pondok pesantren di Provinsi Bengkulu dalam menghadapi nilai-nilai peradaban modern.

Secara teori, menurut Dhofier, pondok pesantren berasal dari dua suku kata, yaitu pondok dan pesantren. Dua kata tersebut tidak bisa dipisahkan dalam pembahasannya sebab setiap membahas pesantren berarti juga membahas konsep pondok. Istilah pondok, berasal dari kata dalam bahasa Arab, yaitu funduk, yang berarti rumah penginapan, ruang tidur, asrama, atau wisma sederhana. Dalam konteks keindonesiaan, kata pondok sering dipahami sebagai tempat penampungan sederhana bagi para pelajar atau santri yang jauh dari tempat asalnya. ${ }^{6}$ Pondok

${ }^{3}$ Suparman Ibrahim Abdullah (ed.), $M$ a'had 'Aly: Profil Pendidikan Tinggi Pondok Pesantren di Indonesia, (Responsible DevelopmentInternational RDI), 2005), h. 4-5

${ }^{4}$ Zeimek.Pesantren dan perubahan sosial. (Jakarta: P3M, 1986)., h. 138

5 Karel A. Steenbrink, Pesantren, Madrasah, Sekolah (Jakarta: LP3ES. 1986), h. 109

${ }^{6}$ Zamakhsyari Dofier, Tradisi Pesantren: Studi Pandangan juga berarti "asrama" dan tempat murid-murid belajar mengaji.? Kata ini sesungguhnya sering digunakan secara bergantian dan bahkan secara terpisah jika dikaitkan dengan pendidikan Islam, maka maksudnya adalah pesantren. Selanjutnya, dari segi bahasa terdapat ragam pengertian mengenai kata pesantren. Dhofier mendefenisikan kata peantren berasal dari kata ' $p e$ ' di depan dan akhiran 'an' yang berarti tempat tinggal para santri. Mengutip pendapat Jhons, pesantren adalah berasal dari bahasa Tamil yang berarti guru mengaji. Sedangkan C.C. Berg berpendapat bahwa istilah tersebut berasal dari istilah shastri yang dalam bahasa India berarti orang yang tahun buku-buku suci agama Hindu. ${ }^{8}$

Dengan mengutip pendapat Nurcholis Madjid, Hanun Ashrohah menyatakan bahwa ada dua pendapat yang bisa dipakai untuk melihat asalusul perkataan santri yang menjadi kata dasar dari pesantren. Pertama, adalah pendapat yang mengatakan bahwa santri berasal dari kata sastri dari bahasa Sansakerta, yang berarti melek huruf. Kedua, adalah pendapat bahwa kata santri berasal dari bahasa Jawa cantrik yang artinya seseorang yang mengabdi kepada seorang guru, sebab cantrik selalu mengkuti kemana saja gurunya menetap dengan tujuan dapat belajar darinya mengenai suatu keahlian. ${ }^{9}$

Mastuhu secara sederhana mendefenisikan pesantren dengan melihat karakteristiknya adalah tempat belajar para santri. Secara teknis pengertian pesantren adalah lembaga pendidikan tradisional Islam ${ }^{10}$ untuk mempelajari,

Hidup Kiyai dan Visinya Mengenai Masa Depan Indonesia, (Jakarta: LP3S, 2011), cet-IX., h. 41

7 Arief Subhan, Lembaga Pendidikan Islam di Indonesia Abad 20; Pergumulan Antara Modernitas dan Identitas, (Jakarta: Prenada Media Grup, 2012)., h.76

${ }^{8}$ Zamakhsyari Dofier, Tradisi Pesantren: Studi Pandangan..., h. 41

9 Hanun Ashrohah, Pelembagaan Pesantren; Asal Usul dan Perkembangan Pesantren di Jawa, (Jakarta: Departemen Agama Rl, 2004), h. 32

10 Sebagai sebuah sistem pendidikan yang merupakan kelanjutan dari sistem pendidikan sebelumnya, pesantren berhasil memadukan sistem pendidikan Islam -yang di dalamnya diajarkan ajaran Islam-dengan budaya lokal yang mengakar pada saat itu. Upaya pemaduan antara ajaran Islam dengan budaya lokal itu, merupakan ciri penyebaran Islam pada masa awal Islam, yang mengutamakan kelenturan dan toleransi terhadap keyakinan dan nilai-nilai yang hidup subur 
memahami, mendalami, menghayati dan mengamalkan ajaran Islam dengan menekankan pentingnya moral keagamaan sebagai pedoman perilaku sehari-hari." Mengawali abad ke-20, keberadaan pesantren semakin pesat tumbuh dan berkembang dengan berbagai variannya. Pertumbuhan dan perkembangan ini seiring dengan gerakan pembaharuan Islam di Indonesia yang dalam istilah Ricklefs seperti dikutip Arief Subhan, 'suatu zaman baru sedang menyingsing, yang ditandai dengan gerakan pembaharuan Islam. ${ }^{12}$ Gerakan pembaharuan Islam ini dimulai dari wilayah Timur Tengah yang tersebar luas hingga ke Indonesia.

Efek dari gerakan pembaharuan Islam ini juga dirasakan dunia pesantren. Salah satunya adalah kritik yang disampaikan Mahmud Yunus atas sistem pembelajaran tradisional yang berlaku di pesantren, 'menurut guru saya (Syekh M. Thaib Umar) bahwa sistem halakah itu dapat mengeluarkan alim besar kurang lebih seorang dalam seratus orang, sisanya 99 orang hanya menolong-nolong beli minyak. ${ }^{33}$ Pernyataan ini merupakan kritik yang sangat pedas terhadap tradisi pesantren tradisional yang menggunakan sistem halakah, hingga saat inipun masih ada yang menggunakan sistem ini. Tonggak sejarah dilakukannya pembaharuan sistem pendidikan pesantren ini ditandai Mahmud Yunus dengan didirikannya Sekolah Adabiyah (Adabiyah School) oleh Abdullah Ahmad di Padang pada tahun $1909^{14}$. Inilah sekolah Islam yang

di masyarakat sejak sebelum Islam datang ke Nusantara. Lihat Suteja, "Pola Pemikiran Kaum Santri:Mengaca Budaya Wali Jawa", dalam Pesantren Masa Depan: Wacana Pemberdayaan dan Transformasi Pesantren,, ed. Marzuki Wahid.et.all. (Bandung: Pustaka Hidayah, 1999), h. 77.

${ }^{11}$ Mastuhu, Dinamika Sistem Pendidikan Pesantren; Suatu Kajian Tentang Unsur dan Nilai Sistem Pendidikan Pesantren, (Jakarta: INIS, 1994), h.55

12 Arief Subhan, Lembaga Pendidikan Islam di Indonesia..., h. 88

${ }^{13}$ Mahmud Yunus, Sejarah Pendidikan Islam di Indonesia, (Jakarta: Mutiara Sumber Widya, 1995), cet. Ke-5., h. 58

14 Meski sudah mulai digagas pendiriannya pada tahun 1909 dengan mendirikan Madrasah Diniyyh, secara kelembagaan Adabiyah School berdiri pada tahun 1914 yang kemudian mendapat pengesahan dari Pemerintahan Kolonial Belanda setahun kemudian, tepatnya tanggal 23 Oktober 1915, sejak itulah Adabiyah School resmi berdiri dalam sebuah badan usaha pendidikan mulai dari Taman Kanak-kanak sampai pendidikan tinggi, pada tahun 1962 barulah kemudian Syarikat Usaha Adabiyah ini ditingkatkan menjadi Yayasan Adabiyah pertama menggunakan meja, kursi dan papan tulis. Sekolah ini juga merupakan eksperimen terhadap modernisasi pendidikan Islam dengan mengadopsi sistem pendidikan Belanda.

Modernisasi pendidikan tersebut, sebagaimana didefinisikan Mochtar Buchori, adalah upaya melakukan reformasi pendidikan, yaitu berupa langkah-langkah nyata untuk memperbaiki seluruh kekurangan yang terdapat dalam sistem pendidikan. Tilaar membagi reformasi pendidikan menjadi dua lingkup, yaitu (1) reformasi pendidikan secara internal, yaitu memberikan kewenangan kepada sekolah untuk melakukan upaya perbaikan sistem pendidikan yang diselenggarakan dan (2) reformasi pendidikan secara eksternal, yaitu melakukan perubahan sistem pendidikan sebagai bagian dari reformasi bidang kehidupan lainnya seperti politik, ekonomi, sosial dan budaya. ${ }^{15}$

Pengertian peradaban secara sederhana adalah kumpulan sebuah identitas terluas dari seluruh hasil budi daya manusia, yang mencakup seluruh aspek kehidupan manusia baik fisik (misalnya bangunan, jalan), maupun non-fisik (nilai-nilai, tatanan, seni budaya maupun iptek), yang teridentifikasi melalui unsur-unsur objektif umum, seperti bahasa, sejarah, agama, kebiasaan, institusi, maupun melalui identifikasi diri yang subjektif. ${ }^{16}$ Istilah "peradaban" dalam bahasa Inggris disebut civilization atau dalam bahasa asing lainnya peradaban sering disebut bescahaving (Belanda) dan die zivilsation (Jerman).

Malinowsky dalam Mudji Sutrisno mengatakan bahwa civilization sebagai aspek khusus dari kebudayaan yang lebih maju. J. Maritain menekankan aspek rasional dan moral pada kebudayaan (culture), dan aspek sosial, politik dan institusional pada peradaban

dengan nama Yayasan Syarikat Usaha Penyelenggara SekolahSekolah Adabiyah, dan didaftarkan pada Pengadilan Negeri Padang tanggal 23 April 1962 No. 44. Lihat mengenai perjalanan lembaga ini dalam Amirsyahruddin, Integrasi Imtaq dan Iptek dalam Pandangan H. Abdullah Ahmad, (Padang: Syamsa Offset, 1999), h. 47-58

${ }^{15}$ Mochtar Buchori, Pendidikan Antisipatoris, (Yogyakarta: Kanisius, 2001), h. 75

${ }^{16}$ KBI. Kamus Bahas Indonesia, (Jakarta: Pusat Bahasa, Departemen Pendidikan Nasional, 2008), h. 9 
(civilization). ${ }^{17}$ Ada juga yang berpendapat bahwa kata civilization berasal dari kata "city" yang berarti "Kota". Sebagian lainnya berpandangan bahwa istilah tersebut adalah serapan dari bahasa Yunani dari kata civitas yang juga berarti kota. ${ }^{18} \mathrm{Ada}$ pula yang berpendapat kata zivilization pertama kali muncul dari bahasa Francis pada tahun 1734 terbentuk dari kata civilise yang berarti bersifat perkotaan. ${ }^{19}$

Sementara itu Arnold Toynbee menyatakan peradaban adalah kebudayaan yang telah mencapai taraf perkembangan teknologi yang sudah lebih tinggi. Pengertian lain menyebutkan bahwa peradaban adalah kumpulan seluruh hasil budi daya manusia, yang mencakup seluruh aspek kehidupan manusia, baik fisik (misalnya bangunan, jalan), maupun non-fisik (nilai-nilai, tatanan, seni budaya, maupun iptek). ${ }^{20}$

M. Abdul Karim mengatakan peradaban adalah bagian-bagian dari kebudayaan yang memiliki sistem teknologi, seni bangunan, seni rupa, sistem kenegaraan dan ilmu pengetahuan yang luas. Ditegaskan lagi bahwa pengertian umum yang dipakai adalah peradaban merupakan bagian dari kebudayaan yang bertujuan untuk memudahkan dan mensejahterakan hidup. ${ }^{21}$ Sementara De Haan dalam Karim mengatakan peradaban adalah lawan dari kebudayaan. Peradaban adalah seluruh kehidupan sosial, politik, ekonomi, dan teknologi. Sedilot sebagaimana yang dikutip oleh Karim juga mengatakan bahwa peradaban merupakan khazanah pengetahuan dan kecakapan teknis yang meningkat dari angkatan ke angkatan dan sanggup berlangsung terus-menerus. Lebih lanjut dengan mengutip Beals dan Hoiyer, Karim mengatakan bahwa peradaban sesungguhnya hampir sama-sama dengan kebudayaan, hal ini jika dipandang dari aspek kualitas, perbedaannya

${ }^{17}$ Mudji Sutrisno, Filsafat Kebudayaan-Ihtiar Sebuah Teks, (Jakarta: Hujan Kabisat, 2008), Cet.ke-1, h.3

18 Nabilah Hasan Muhammad, Fi Tarîkh al-Hadârah alIslâmiyah, (Iskandariyah: Daar al-Ma'rifah, tt), h. 8.

19 Ahmad al-Qashash, Nusyû al-Hadârah al-Islâmiyah, (Maktabah Syamilah, al-Ishdar al-Tsani, tt), h. 11.

${ }^{20}$ Arnol Toynbee, The Disintegrations of Civilization dalam Theories of Society, (New York, The Free Press, 1965), h. 1355

${ }^{21}$ M.Abdul Karim, Sejarah Pemikiran dan Peradaban Islam, (Yogyakarta : Pustaka BOOK Publisher, 2009)., h. 34-35. tampak dari sisi kuantitas, isi dan kompleks pola-polanya. ${ }^{22}$

Badri Yatim mengungkapkan bahwa peradaban adalah sesuatu yang dipakai untuk bagianbagian dan unsur-unsur dari kebudayaan yang halus dan indah. ${ }^{23}$ Sementara, Chudoba dan J. Schall dalam Mudji Sutrisno mejelaskan bahwa peradaban adalah gagasan-gagasan, karya-karya, alat-alat, adat istiadat dan pranata-pranata dalam masa lampau yang tak dapat diubah. ${ }^{24}$

Huntington juga mendefinisikan lebih rinci lagi bahwa peradaban adalah pengelompokan tertinggi dari orang-orang yang tingkat identitas budaya paling luas yang dimiliki oleh orang sehingga membedakannya dari spesies lain. la dibatasi oleh unsur-unsur objektif, yaitu, bahasa, sejarah, agama, adat istiadat, lembaga-lembaga. Juga dibatasi unsur subjektif yaitu identifikasi diri dari orang-orang tersebut. Budaya dalam hal ini diwakili oleh berbagai wilayah, baik desa, daerah, kelompok etnis, kebangsaan, kelompok agama dan lain-lain yang semuanya mempunyai tingkat keragaman budaya yang berbeda-beda. Dari perbedaan inilah akan menuju pada satu persamaan yaitu menjadi sebuah peradaban. ${ }^{25}$

Seperti yang telah dijelaskan sebelumnya, peradaban secara umum mengacu pada aspek budaya yang paling tinggi dan paling halus dalam kehidupan manusia. Konsep Islam sebagai peradaban telah dimiliki oleh Islam saat diturunkan sebagai agama (din). ${ }^{26}$ Hal itu disebabkan oleh

\footnotetext{
${ }^{22}$ M.Abdul Karim, Sejarah Pemikiran... h. 35

${ }^{23}$ Badri Yatim, Sejarah Peradaban Islam, (Jakarta: PT. Raja Grafinda Persada, 1990), p 2

${ }^{24}$ Sutrisno Mudji, Filsafat Kebudayaan-Ihtiar Sebuah Teks, (Jakarta: Cetekan Pertama, Hujan Kabisat)., 2008, h.3

${ }^{25}$ Samuel H. Huntington, The Clash of Civilization... h. 25-40

${ }^{26}$ Nasr dan Smith mengatakan bahwa Islam diakui secara jamak sebagai agama sekaligus peradaban (Islam is both a religion and a civilization), karena Islam bukan hanya sebuah agama, melainkan creator dan spirit yang hidup bagi sebuah peradaban besar dunia yang sejarahnya terbentang luas lebih dari 14 abad, "Islam is not only a religion; it is also the creator and living spirit of major world civilization with a long history stretching over fourteen centuries. Demikian juga Bernard Lewis, la mencatat bahwa: "Islam -the offspring of Arabia and the Arabian Prophet-was not only a system of belief and cult. It was also a system of state, society, law, thought and art, a civilization with religion as its unifying eventually dominating, factor." Lihat dalam Seyyed Hossein Nasr \& Huston Smith, Islam: Religion, History, and Civilization, (Lahore-Pakistan: Suhail Academy, 2005), h. xi. Dan juga temukan statement ini dalam Bernard Lewis, The Arab in History, (New York: Harper \& Row, Publisher, 1967), h. 113.
} 
makna dari din itu sendiri adalah struktur hukum dan susunan kekuasaan serta kecenderungan manusia untuk mencari pemerintah yang adil dan membentuk masyarakat yang patuh hukum. Islam turun sebagai agama secara sempurna dan terlaksana secara langsung di tempat yang bernama Madinah yang sebelumnya adalah Yathrib. Maka terbentuklah akar kata yang baru, madana dari kata din dan madinah yang bermakna mendirikan kota, membangun, memajukan dan memurnikan serta menjunjung martabat ${ }^{27}$, dalam perkembangannya istilah peradaban ini berkembang dengan ragam nama dan istilah, yaitu hadarah,tsaqofah dan tamaddun.

Antony Giddens memaknai realitas kemodernan (modernisme/modernitas) sebagai pola hidup sosial atau organisasi masyarakat manusia, yang muncul di Eropa mulai dari sekitar abad ke-17 dan seterusnya, yang kemudian begitu mempengaruhi dunia. Sementara Lawrence Cahoone mengartikan realitas kemodernan sebagai keseluruhan ide, prinsip, dan pola interaksi, yang muncul dari berbagai macam bidang; mulai dari filsafat hingga ekonomi, yang menjadi dasar perkembangan masyarakat dan kultur Eropa Barat dan Tengah serta Amerika, sejak abad ke-14 hingga abad ke-20. ${ }^{28}$

Islam mempunyai sifat eklektik terhadap banyak hal baru, tapi Islam sebagai agama, sebagai identitas ideologi agama atau juga masyarakat, tidak "asal ambil" terhadap segala materi dari luar. Kalau poin sebelumnya membahas penyerapan atau sifat eklektis maka poin disini adalah sistem nilai yang tetap. Ada sebuah adagium yang dipegangi Gus Dur yaitu al-akhżu bi al-jadîd ma'a al- muhâfaah alâ qadîm al-sâlih, (mengambil sesuatu yang baru bersamaan dengan penjagaan terhadap sesuatu yang lama dan masih relevan) dan adagium mâ lâ yudraku kulluh lâ yutraku kulluh.29

${ }^{27}$ Untuk penjelasan ini dapat ditelusuri dalam Al-Attas, Islam, Religion and Morality, dalam Prolegomena to the Methapgysics of Islam, (Malaysia: Istac, tp, 1995)., h. 43. Juga dapat dilihat dalam Ibn Mander, Lisin al-'Arab al-Mulei, (Beirut: Daar Al-Jayl, 1988)., p 402

28 Lihat mengenai hal ini dalam Emmanuel Wora, Perenialisme, Kritik atas Modernisme dan Postmodernisme, (Yogyakarta: Kanisius, 2006), h. 38-39.

29 Abdurrahman wahid, Standarisasi Sarana IImiah di Pondok Pesantren, dalam Menggerakkan Tradisi, (Yogyakarta; LKiS, 2010), h. 167-168

\section{Metodologi}

Penelitian ini menggunakan metode deskriptif kualitatif. Subjek penelitian ini adalah pondok pesantren yang berada dalam wilayah pemerintahan Provinsi Bengkulu. Dalam hal ini, pondok pesantren di Bengkulu yang dianggap dapat mewakili ketercapaian dari tujuan penelitian ini adalah Pondok Pesantren Pancasila Kota Bengkulu, Pondok Pesantren Hidayatullah Kota Bengkulu, Pondok Pesantren Al-Hasanah Kota Bengkulu, Pondok Pesantren Makrifatul IImi Bengkulu Selatan, Pondok Pesantren Al-Quraniah Bengkulu Selatan, Pondok Pesantren Darussalam Kota Bengkulu, Pondok Pesantren Salafiyah Sentot Alibasya Bengkulu dan Pondok Pesantren ar-Rhaudha Seluma Bengkulu.

\section{Potensi Pondok Pesantren di Provinsi Bengkulu dalam menghadapi Nilai-nilai Peradaban Modern}

Peradaban umat manusia di abad 21 merupakan era teknologi informasi yang sangat canggih, Jhon Naisbit menyatakan bahwa peradaban saat ini bergerak kearah kemampuan berkomunikasi apa saja kepada siapapun, di manapun, berbentuk apapun, baik itu datasuara-tulisan atau gambar, dengan menggunakan kecepatan suara. ${ }^{30}$ Demikianlah gambaran arus modernisasi dalam bentuk teknologi informasi, yang di istilahkan oleh Yasraf Amir Piliang dengan sebutan dunia yang dilipat.

Berhadapan dengan kondisi dan realitas di atas, pondok pesantren dituntut untuk dapat menjadi oase ditengah kegersangan tata nilai yang berorientasi humanis. Oleh karena itu, sebagaimana yang telah dijelaskan pada bagian sebelumnya, bahwa respon pondok pesantren mutlak diperlukan dengan memaksimalkan peluang yang ada serta mendayagunakan potensi yang dimiliki.

${ }^{30}$ Chairil Anwar, Islam dan Tantangan... h. 64-65, lihat juga mengenai dunia yang dilipat dalam Yasraf Amir Piliang, Sebuah Dunia Yang di Lipat; Realitas Kebudayaan Menjelang Millenium Ketiga dan Matinya Postmodernisme, (Bandung: Mizan Pustaka, 1998)., h. 27. Yasraf menjelaskan bahwa pergerakan pada dunia informasi adalah real, meski manusia tidak bisa melihatnya, akan tetapi dapat merasakannya. 
Berkenaan dengan potensi pondok pesantren di Bengkulu, secara kuantitatif dapat dilihat dari jumlah pondok pesantren yang berdiri dan berkembang di provinsi ini. Jika dilihat secara nasional, maka dapat dilihat sejak Indonesia merdeka. Pertumbuhan dan perkembangan pesantren semakin pesat. Pada tahun 1955 Departemen Agama mencatat terdapat 30.368 pesantren dengan santri sejumlah 1.392.159 orang. Kemudian pada tahun 1972 jumlah pesantren sekitar 32.000 dengan jumlah santri sekitar 2 juta orang. ${ }^{31}$ Namun berdasarkan data statistik Ditjen Kelembagaan Islam, Departemen Agama Republik Indonesia pada tahun 1980 jumlah pesantren di Indonesia hanya sekitar 5.373 buah dengan jumlah santri 1.238.967 orang. Ini berarti pada tahun tersebut terjadi penurunan yang sangat drastis. Namun pada tahun 2005 jumlah pesantren kembali meningkat menjadi 14.798 pesantren dengan santri berjumlah 3.464.334 orang. ${ }^{32}$ Pada tahun 2011, Kepala Pusat Pusat Pengembangan Penelitian dan Pendidikan Pelatihan Kementerian Agama $\mathrm{H}$. Abdul Jamil mengatakan, jumlah santri pondok pesantren di 33 provinsi di seluruh Indonesia mencapai 3,65 juta yang tersebar di 25.000 pondok pesantren dan pada tahun 2012 data pesantren meningkat menjadi 27.230 buah. ${ }^{33}$ Khusus di Provinsi Bengkulu terdapat 54 Pondok Pesantren dengan total jumlah santri diperkirakan sekitar 1500 orang, menurut data ini, maka terdapat kurang lebih potensi 3000 santri yang dapat dijadikan sumber input dari 9 Kabupaten dan 1 Kota di Provinsi Bengkulu.

Secara kualitatif, potensi yang dapat dijadikan modal bagi pondok pesantren di Provinsi Bengkulu dalam rangka menghadapi nilai-nilai peradaban modern adalah potensi yang berasal dari tradisi pesantren itu sendiri. Dhofier menjelaskan beberapa elemen dari tradisi pesantren yang ada di Indonesia, yaitu kiai, santri, masjid, pondok dan kitab kuning. Kelima elemen ini adalah potensi besar yang

${ }^{31}$ Nurcholish Madjid, Bilik-Bilik Pesantren, Dian Rakyat, Jakarta, h. xix

${ }^{32}$ Abd. Wahid Hasyim, Ringkasan Disertasi "Pesantren dan Politik" UIN Jakarta: Jakarta, 2007, h. 5

33 Lihat. http://ditpdpontren.kemenag.go.id/tag/bankindonesia/. Diakses tanggal 25 Desember 2016. dapat dijadikan benteng bagi pondok pesantren guna menghadapi tantangan modernitas melalui penggalian nilai-nilai Islam. Khususunya di Bengkulu, potensi ini belum diberdayakan secara maksimal. Bagaimanapun penggalian nilai-nilai Islam yang dapat menghadang arus peradaban modern diperlukan juga pengkajian mendalam melalui kitab-kitab klasik yang dalam tradisi pesantren disebut kitab kuning. Kelangkaan sumber daya pengajar menjadi sebab yang hampir di alami seluruh pesantren di Provinsi Bengkulu.

Sebagaimana ide awal pendirian pesantren, pesantren hadir dilandasi sekurang-kurangnya oleh dua alasan. Pertama, pesantren dilahirkan untuk memberikan respon terhadap situasi dan kondisi sosial suatu masyarakat yang berada dalam keruntuhan sendi-sendi moral yaitu melalui transformasi nilai yang ditawarkan (amar ma'ruf, nahyi munkar). Kedua, salah satu tujuan pesantren adalah menyebarluaskan informasi ajaran tentang universalitas Islam ke seluruh pelosok nusantara yang berwatak pluralis, baik dalam dimensi kepercayaan, budaya maupun kondisi sosial masyarakat.

Hasil penelitian Munir membuktikan bahwa pesantren sangat besar kontribusinya bagi penyebaran ajaran Islam, terutama alumninya. Mereka banyak melakukan hal penting untuk pengembangan masyarakat. Upaya pembangunan masyarakat dengan sekolah-sekolah biasanya melalui eksternalisasi tradisi Islam ke tengahtengah masyarakat melalui penyebaran alumni sebagai pemimpin atau pendirian sekolah baru, imam masjid, atau langgar. Meskipun demikian, mereka tidak memimpin pesantren, alumni pesantren biasanya masih mengambil bagian sebagai pemimpin dalam masyarakat di bidang ajaran Islam. Mereka selalu melakukan pendidikan agama kepada masyarakat di sekitarnya dengan fokus pada langgar atau masjid, atau sering disebut "kiai langgar." ${ }^{34} \mathrm{Hal}$ ini juga menjadi potensi bagi pesantren, sebab melalui alumni maka masyarakat akan melihat bahwa

34 Munir, "The Continuity and Change of Pesantren Tradition: Study Network Main Pesantren and Alumni Pesantren in Kabupaten OKU Timur, South Sumatra", Jurnal Pendidikan Islam, Volume 5, Number 2, December 2016/1438 
pesantren dapat membentuk pribadi yang unggul berdasarkan nilai-nilai ajaran Islam.

Potensi lainnya yang dapat menjadi modal bagi pondok pesantren dalam menghadapi peradaban modern adalah ilmu pengetahuan dan teknologi. Pada pembahasan sebelumnya telah dikemukakan bahwa ilmu pengetahuan dalam Islam memiliki dimensi yang sangat luas, dan tauhid ilmu pengetahuan menjadi dasar bagi pengembangannya. Peran Islam dalam perkembangan iptek pada dasarnya ada dua. Pertama, menjadikan akidah Islam sebagai paradigma ilmu pengetahuan. Paradigma inilah yang dimiliki umat Islam, bukan paradigma sekuler seperti yang ada sekarang. Paradigma Islam ini menyatakan bahwa Akidah Islam wajib dijadikan landasan pemikiran (qa'idah fikriyah) bagi seluruh ilmu pengetahuan. Ini bukan berarti menjadi Akidah Islam sebagai sumber segala macam ilmu pengetahuan, melainkan menjadi standar bagi segala ilmu pengetahuan. Maka ilmu pengetahuan yang sesuai dengan Akidah Islam dapat diterima dan diamalkan, sedang yang bertentangan dengannya, wajib ditolak dan tidak boleh diamalkan. Kedua, menjadikan syariah Islam (yang lahir dari akidah Islam) sebagai standar bagi pemanfaatan iptek dalam kehidupan seharihari. Jadi, yang harus mengaitkan dirinya pada prinsip tauhid adalah pemilik atau pencari ilmunya, bukan ilmu itu sendiri. Begitu pula yang harus mengakui bahwa manusia berada dalam suasana dominasi ketentuan akhir Tuhan secara metafisik dan aksiologis adalah manusia selaku pencari ilmu, bukan ilmu pengetahuannya.

Potensi berikutnya yang dijadikan modal bagi pondok pesantren yang ada di Bengkulu dalam rangka menghadapi nilai-nilai modern adalah potensi dibidang ekonomi. Kiprah pesantren dalam upaya mengangkat harkat dan martabat masyarakat terutama dalam bidang ekonomi, dapat dilihat dari partisipasi pesantren dalam memasyarakatkan koperasi. Di Indonesia, ide koperasi pertama kali disampaikan oleh Bung Hatta, dan mulai dikampanyekan secara luas pada tahun 1930-an. Saat itu tidak banyak masyarakat yang menyambut gagasan tersebut. Mereka tidak peduli karena masih berada dalam kondisi ekonomi yang lemah dan terjajah, di samping belum memahami dan mengetahui kelebihan-kelebihan koperasi. Akan tetapi, dalam kondisi seperti itu, pesantren menyambut baik gagasan tersebut. Bahkan pesantren tercatat sebagai pihak yang pertama kali menyambut dan mengembangkan sektor koperasi. Pada awalnya tentu masih dijalankan dengan pengelolaan manajemen yang amat sederhana. Akan tetapi, lambat laun koperasi pondok pesantren berkembang perekonomian di lingkungan santri. Selain memberikan kontribusi berharga bagi pengembangan masyarakat dalam arti fisik misalnya keterampilan pesantren juga berandil besar dalam penggalakan wirausaha. Di lingkungan pesantren, para santri di didik menjadi manusia yang bersikap mandiri dan berjiwa wirausaha. Mereka giat berusaha dan bekerja secara independen tanpa menggantungkan nasib pada orang lain atau lembaga pemerintah dan swasta. Para santri mau bekerja apa saja, asal halal. Tidak pernah terdengar, seorang santri kebingungan mencari lowongan pekerjaan dan terpaksa jadi penganggur.

Hal yang patut disyukuri adalah hampir seluruh pondok pesantren di Provinsi Bengkulu memiliki amal usaha yang dijadikan sebagai penopang bagi keberlangsungan operasional pesantren, sebagian besar membangun usaha perkebunan, peternakan dan pertanian, dan sebagian lainnya melalui usaha perdagangan. Pada era modern saat ini, dibutuhkan kemandirian pesantren dalam mengelola dirinya agar dapat bertahan dalam menghadapi modernisasi dan globalisasi. Keberadaan amal usaha ini bukan semata-mata untuk operasional pesantren dan atau untuk peningkatan kesejahteraan pengasuh dan para guru di pesantren, melainkan digunakan sebagai media bagi pembinaan mentalitas santri dalam menghadapi peradaban modern.

Jika ditinjau dari aspek konsumsi, pondok pesantren merupakan kekuatan yang cukup besar. Jumlah santri di Provinsi Bengkulu yang mencapai ribuan tersebut, maka kebutuhan pangan, pakaian dan peralatan serta kebutuhan sehari-hari sangat besar. Upaya memenuhi kebutuhan dengan memanfaatkan sumberdaya setempat diharapkan menghasilkan efek ganda pertumbuhan ekonomi. Jadi keberadaan pondok 
pesantren di suatu daerah akan memberikan kesempatan kerja dan peningkatan pendapatan masyarakat sekitarnya.

\section{Strategi Pondok Pesantren di Provinsi Bengkulu Terhadap Nilai-nilai Peradaban Modern}

Minat masyarakat Provinsi Bengkulu terhadap pendidikan formal mempengaruhi perkembangan sistem pendidikan di pesantren. Untuk mengakomodasi minat tersebut, sebagian pesantren yang diteliti pada penelitian mulai mendirikan sekolah formal dengan lisensi pemerintah. Sejak berdirinya sekolah formal inilah, sistem kepemimpinan dan pengelolaan pembelajaran mengalami banyak perubahan. Kasus pada beberapa pondok pesantren di Bengkulu, terlihat tidak lagi dipimpin secara individual oleh kiai tapi dipimpin secara kolektif dengan payung hukum yayasan.

Para santri tidak hanya mempelajari ilmu agama tetapi mereka juga diajarkan ilmu umum seperti Bahasa Inggris, matematika, IPA dan lain sebagainya. Sistem pengajaran terbuka, klasikal, penjenjangan, berdirinya sekolah formal, dan masuknya beberapa mata pelajaran umum merupakan perubahan yang cukup radikal yang terjadi di pondok pesantren. Ternyata, adanya perubahan ini mampu menjaga eksistensi dan kepercayaan masyarakat terhadap pesantren.

Dari beberapa wawancara peneliti dengan informan dalam penelitian ini, ditemukan bahwa fenomena pesantren yang ada di Provinsi Bengkulu menunjukkan, bahwa peluang pondok pesantren di Provinsi Bengkulu adalah dapat dilihat dari fakta sejarah Islam di Bengkulu. Hadirnya Islam di Bengkulu dengan segala variannya ternyata, tidak ada penolakan dan atau juga konflik yang muncul, bahkan sebaliknya, keterbukaan masyarakat terhadap ajaran atau sesuatu yang baru yang lebih baik menandakan adanya peluang bagi pengembangan Pondok Pesantren di Provinsi ini.

Selain itu, peluang bagi keberadaan pondok pesantren di Bengkulu adalah jumlah penduduk Provinsi Bengkulu yang mayoritas muslim dan dukungan masyarakat terhadap peran pesantren. Selanjutnya secara legal formal, pondok pesantren yang ada di Provinsi Bengkulu ini berada dalam naungan Kementerian Agama RI dan Kementerian Pendidikan Nasional. Dengan adanya pengakuan dari kedua kementerian ini, memungkin pula bagi pondok pesantren untuk turut serta dalam kegiatan pembinaan kelembagaan serta perhatian dari pemerintah.

Hal yang paling penting adalah keberadaan pesantren dengan segala dinamikanya di Provinsi Bengkulu sangat relevan dengan tingkat perekonomian masyarakat yang membutuhkan lembaga pendidikan murah berkualitas. Di samping itu tentunya penghargaan masyarakat terhadap tokoh agama menjadi penentu bagi pengembangan pondok pesantren di Bengkulu ini.

Selain peluang yang dimiliki oleh pondok pesantren, terdapat pula ancaman yang siap menghadang, yakni muncul dan berkembangnya opini bahwa pesantren adalah lembaga tradisional yang tertinggal zaman dan tempat membina anak-anak nakal. Sebagai institusi bersahaja seringkali mendapat stigma miring sebagai kamuflase kehidupan karena selalu berkutat dengan persoalan akhirat. Kemudian pesantren juga dicerca sebagai pusat kehidupan fatalis, karena perannya memproduksi pola kehidupan yang meninggalkan dunia materi (zuhud). Bahkan yang lebih 'kasar' ialah ketika pesantren dinobatkan sebagai pusat radikalisme yang menggoyahkan posisi pesantren sebagai "kampung peradaban". 35

Ancaman selanjutnya adalah adanya kebijakan pemerintah mengenai pembiayaan pendidikan dalam bentuk program sekolah gratis dan juga sejumlah subsidi bagi sekolah umum. Tentunya ini mempengaruhi keinginan orang tua untuk menyekolahkan anaknya ke pesantren. Ancaman lainnya adalah berdiri dan berkembangnya sekolah sejenis yang menawarkan pendidikan full time dalam bentuk boarding school, dengan sistem pendidikan yang hampir sama dengan pondok pesantren, namun tidak terikat pada elemen-elemen pesantren serta

35 Djohan Efendi, Pesantren dan Kampung Peradaban (Sebuah Pengantar), dalam: Hasbi Indra, Pesantren dan Transformasi Sosial: Studi Atas Pemikiran K.H. Abdullah Syafi'ie dalam Bidang Pendidikan Islam, Hasan M. Nur (Ed), Cet. 1, (Jakarta: PENAMADANI), hal. xvii. 
ke khasannya pada aspek sains dan teknologi. Ancaman juga muncul karena terdapatnya kesenjangan pola pergaulan pesantren dengan dunia luar, serta berkembangnya paham sekularisme yang tidak lagi menuntut seseorang untuk ahli dalam bidang agama, melainkan menuntut profesionalisme dalam bidang-bidang tertentu dengan memisahkan urusan duniawi dan ukhrowi.

Berangkat dari peluang dan ancaman atau tantangan mengenai keberadaan pondok pesantren di Provinsi Bengkulu tersebut, maka seyogyanya juga dapat dijadikan dasar dalam menyusun strategi pondok pesantren dalam menghadapi nilai-nilai peradaban modern. Oleh karena itu, berdasarkan wawancara dengan beberapa pengasuh pondok pesantren di Provinsi Bengkulu, ditemukan bahwa strategi yang dilakukan dalam menghadapi nilai-nilai peradaban modern paling tidak terbagi dua, yaitu strategi internal yang berkenaan dengan quality inscurance kelembagaan dengan segenap perangkatnya dan strategi eksternal berkenaan dengan peran dan fungsi pondok pesantren di tengah-tengah masyarakat.

Menurut Hamel dan Prahalad, strategi adalah sebagai tindakan yang bersifat inkremental (senantiasa meningkat) dan terus-menerus dan dilakukan berdasarkan sudut pandang tentang apa yang diharapkan oleh para pelanggan di masa depan. ${ }^{36}$ Konsep kebangkitan pondok pesantren dalam rangka menghadapi nilai-nilai peradaban modern ini sesungguhnya berangkat dari sejarah awal berdirinya pesantren itu sendiri. Sejumlah pesantren yang diteliti menunjukkan bahwa mendirikan pesantren merupakan salah satu respon dari para tokoh dan pemerhati pendidikan dalam melihat fenomena modern yang banyak mengakibatkan terjadinya deviasi pada generasi muda, calon penerus bangsa. Karena itulah, di lembaga pendidikan ini nantinya akan ditanamkan nilai-nilai religius secara berkesinambungan dalam sistem pendidikan pondok pesantren.

Pola pendidikan pesantren yang ber-

${ }^{36}$ Freddy Rangkuti, Analisis SWOT Membedah Kasus Bisnis, (Jakarta: Gramedia, 2008), h. 4 kesinambungan dan selalu berulang agar dapat bertahan dan terjadinya perubahan perilaku merupakan tujuan dari pendidikan secara khusus. Hal ini sesuai dengan dengan teori habitus ${ }^{37}$ yang meliput sistem atau perangkat disposisi yang bertahan lama dan diperoleh melalui latihan berulang kali. Kemudian ia lahir dari kondisi sosial tertentu, yakni peradaban modern yang tidak dilandasi nilai-nilai religius, khususnya ajaran Islam menjadi ancaman dan karena itu menjadi struktur yang sudah diberi bentuk terlebih dahulu oleh kondisi sosial yang diproduksikan. Konsep habitus selanjutnya adalah berfungsi sebagai kerangka yang melahirkan dan memberi bentuk kepada persepsi, representasi, dan tindakan seseorang dan karena itu menjadi structuring structures. ${ }^{8} \mathrm{Hal}$ ini tergambar dari pandangan para pengasuh pesantren, bahwa modernisasi merupakan sebuah keharusan dari perubahan zaman, dan diperlukan seperangkat tindakan agar kemudian generasi masa yang akan datang dapat menghadapinya dengan karakteristik ajaran Islam.

Strategi selanjutnya dalam rangka menghadapi nilai-nilai peradaban modern adalah dengan melakukan transformasi nilai-nilai pesantren kedalam kehidupan sosial masyarakat. Sebagaimana tujuan awal pendirian pesantren, maka pesantren dituntut agar mampu menjadi lokomotif perubahan sosial sebagaimana yang telah dijelaskan terdahulu. Adanya perubahan orientasi pesantren tersebut disebabkan oleh perbedaan harapan antara santri pada masa dulu dan santri masa kini. Dulu, santri menghabiskan seluruh waktunya di pesantren untuk menempa iman, ilmu, dan amal, sementara santri sekarang menganggap pesantren sebagai karantina uji batiniah dan lompatan untuk meneruskan ke lembaga sekuler yang lebih tinggi. Tanda itu terlihat dari kebutuhan santri atas ijazah sebagai syarat pokok untuk melanjutkan ke jenjang pendidikan yang lebih tinggi. Akibat pergeseran

${ }^{37}$ Pierre Bourdieu, The Field Of Cultural Production, (Polity Press, Cambridge, 1993)., h. 72

${ }^{38}$ Pierre Bourdieu, The Field Of Cultural... h. 76 lihat juga Siti Ma'rifah, "Pesantren Sebagai Habitus Peradaban Islam Indonesia”, 2015. Jurnal Penelitian, Vol. 10, No. 1, Februari 2016 pada Lembaga Kajian Sosial dan Agama Tasamuh Institute Kudus, Jawa Tengah 
orientasi tersebut pesantren tidak lagi terkesan eksklusif dan teralienasi, melainkan terbuka dan eksis dalam masyarakat. Kenyataan ini sesuai dengan apa yang menjadi konsep dari habitus yaitu sekalipun habitus lahir dalam kondisi sosial tertentu, ia bisa dialihkan ke kondisi sosial yang lain dan karena itu bersifat transformable dan habitus bersifat pra-sadar (pre-conscious) karena ia tidak merupakan hasil dari refleksi atau pertimbangan rasional. 39

Strategi pondok pesantren dalam mengadapi nilai-nilai peradaban modern, harus tetap berkontribusi dalam menjaga peradaban umat. Sebagaimana yang diketahui, bahwa pesantren adalah benteng terakhir peradaban Islam di Indonesia. Hal memungkinkan bagi pesantren untuk memainkan peran dan fungsinya, khususnya di Indonesia yang berideologi pancasila dimana kebebasan beragama menjadi salah satu piranti dalam menjaga keutuhan bangsa. Namun, bila negara tidak lagi mampu memberikan jaminan ini, menurut konsep habitus, maka pondok pesantren dapat berfungsi sebagai kerangka yang melahirkan dan memberi bentuk kepada persepsi, representasi, dan tindakan seseorang dan karena itu menjadi structuring structures..$^{40}$

Kasus pada pondok pesantren yang ada di Provinsi Bengkulu dalam penelitian ini membuktikan bahwa peradaban modern tidak secara vis a vis dihadapi dengan strategi yang tersusun berdasarkan peluang dan ancaman sebagaimana yang dijelaskan pada awal pembahasan ini. Hal ini disebabkan karena pesantren tersebut masih berkutat pada pencaharian identitas dan kekhasan masing-masing. Meskipun demikian, beberapa strategi yang telah dikemukakan oleh para pengasuh pondok pesantren tersebut, menurut hemat penulis sudah berangkat dari kesadaran yang teratur dan berpola, tetapi bukan merupakan ketundukan kepada peraturanperaturan tertentu.

Kesadaran yang teratur dan berpola juga merupakan konsep habitus yang lebih menekankan pada perubahan yang signifikan.

39 Pierre Bourdieu, The Field Of Cultural... h. 76 lihat juga Siti Ma'rifah, Pesantren Sebagai Habitus... 2005

${ }^{40}$ Pierre Bourdieu, The Field Of Cultural..., h. 80.
Senada dengan konsep ini seperti apa yang telah dilakukan oleh Wahid Hasyim sebagai tokoh pesantren di Indonesia, dalam mengadakan perubahan terhadap sistem pendidikan pesantren, ia membuat perencanaan yang matang. la tidak ingin gerakan ini gagal di tengah jalan. Untuk itu, ia mengadakan langkah-langkah dengan (1) menggambarkan tujuan dengan sejelas-jelasnya, (2) menggambarkan cara mencapai tujuan itu, dan (3) memberikan keyakinan dan cara bahwa dengan sungguh-sungguh tujuan dapat dicapai.

Strategi berikutnya yang kini dikembangkan oleh pondok pesantren yang ada di Provinsi Bengkulu adalah mulai bergerak membuat kerjakerja integrasi ilmu. Meskipun secara metodologis, pesantren di bengkulu mulai mengembangkan pengajarannya. Namun Pada level tertentu, kerjakerja integrasi ilmu antar fardhu'ain dan fardhu kifayah belum diorientasikan secara maksimal. Kajian-kajian ilmu fardhu kifayah seperti logika, filsafat Islam, metafisika, kalam, kedokteran dan matematika juga sangat sedikit. Warisan tradisi intelektual para ulama' dan cendekiawan terdahulu belum dipelajari secara maksmal. Ilmu fardhu kifayah yang melibatkan kajian-kajian tentang ekonomi Islam, sosiologi Islam, fisika Islam, kedokteran Islam dan kajian tentang alam ditempatkan secara hierarkis, masih terkesan dualis. Hal ini didukung dengan konsep habitus yang dapat terarah kepada tujuan dan hasil tindakan tertentu, tetapi tanpa ada maksud secara sadar untuk mencapai hasil-hasil tersebut dan juga tanpa penguasaan kepandaian yang bersifat khusus untuk mencapainya. ${ }^{41} \mathrm{Hal}$ ini karena sesuai dengan jati dirinya, pesantren adalah lembaga pendidikan Islam yang memiliki tugas utama menjaga peradaban Islam khususnya di Indonesia.

Secara praktis, strategi pondok pesantren di Provinsi Bengkulu dalam merespon nilai-nilai peradaban modern adalah dengan langkah melakukan upaya modernisasi manajemen pengelolalan pendidikan. Ini tampak di Pondok Pesantren Darussalam Kota Bengkulu yang melakukan upaya modernisasi Pondok Pesantren.

${ }^{41}$ lihat Siti Ma'rifah, "Pesantren Sebagai Habitus" .... Jurnal Penelitian, Vol. 10, No. 1, 
Hal ini menyangkut aspek manajemen dan pengelolaan pondok pesantren. Pada aspek ini ada beberapa hal yang terus dibenahi agar tertata dengan baik, yaitu administrasi, organisasi, tenaga pendidik dan kependidikan, supervisi dan evaluasi. Proses modernisasi manajemen pendidikan ini mengacu bahwa setiap individu dalam organisasi mempunyai wewenang yang diatur oleh berbagai peraturan kebijakan dan ketetapan hukum sehingga diperlukan pembagian tugas sesuai dengan spesialis yang dimiliki individu. Birokrasi merupakan usaha untuk menghilangkan tradisi organisasi yang membuat keputusan secara emosional atau ikatan kekeluargaan sehhingga mengakibatkan organisasi tidak efektif. Birokrasi juga tidak ada hubungannya dengan prosedur yang berbeliit-belit, penundaan pekerjaan, ketidakefisienan, dan pemborosan. ${ }^{42}$

Manajemen dan pengelolaan pondok pesantren ini merupakan sesuatu yang penting untuk diterapkan untuk melihat peluang ke depan dan untuk mengukur kondisi dan kemampuan pondok pesantren, baik secara manjerial maupun financial yang tentunya disesuaikan dengan karakteristik pondok pesantren dan visi, misi, dan fungsinya. Menurut Soebagio Admodiwiro, manajemen merupakan proses sosial yang direncanakan untuk menjamin kerja sama, partisipasi dan keterlibatan sejumlah orang dalam mencapai sasaran dan tujuan tertentu yang ditetapkan secara efektif. Manajemen mengandung unsur bimbingan, pengarahan, dan pengarahan sekelompok orang terhadap pencapaian sasaran umum. Sebagai proses sosial, manajemen meletakkan fungsinya pada interaksi orang-orang, baik yang berada di bawah maupun berada di atas posisi operasional seseorang dalam suatu organisasi. ${ }^{43}$

Menyederhanakan strategi ini dan berdasarkan fungsinya, maka dapat disimpulkan bahwa

42 administrasi dapat juga diartikan sebagai suatu kegiatan atau usaha untuk membantu, melayani, mengarahkan atau mengatur semua kegiatan didalam mencapai tujuan. Lihat dalam Ngalim Purwanto, Administrasi dan Supervisi Pendidikan (Bandung: Remaja Rosdakarya, 1995), h. 1. Lihat juga . http:// www.kompasiana.com/fajro14/teori-teori-manajemen-pendidi kan_55004c1fa333115b745104b5. diakses tanggal 10 April 2017

43 Soebagio Admodiwiro, Manajemen Pendidikan Indonesia (Jakarta: Arda Dizya Jaya, 2000), h. 5 paling tidak tiga hal yang mesti digarap oleh pondok pesantren yang sesuai dengan jati dirinya. Pertama, pesantren sebagai lembaga pendidikan pengkaderan ulama. Fungsi ini tetap harus melekat pada pesantren, karena pesantren adalah satu-satunya lembaga pendidikan yang melahirkan ulama. Hal ini penting mengingat pesantren dituntut dapat menjawab kebutuhan pasar, mengutip Nanang Fattah, berdasarkan pendapat Shrode dan Voich tujuan manajemen adalah produktivitas dan kepuasan seperti peningkatan mutu pendidikan, pemenuhan kesempatan kerja pada pembangunan daerah/ nasional serta tanggung jawab sosial. Tujuan tersebut ditentukan berdasarkan pengkajian terhadap situasi dan kondisi organisasi, seperti kekuatan dan kelemahan, peluang, dan ancaman. ${ }^{44}$

Namun demikian, tuntutan modernisasi dan perkembangan IPTEK mengharuskan ulama memiliki kemampuan lebih, kapasitas intelektual yang memadai, wawasan, akses pengetahuan dan informasi yang cukup serta responsif terhadap perkembangan dan perubahan. Kedua, pesantren sebagai lembaga pengembangan ilmu pengetahuan khusus agama Islam. Pada tatanan ini, pesantren masih dianggap lemah dalam penguasaan ilmu dan metodologi. Pesantren hanya mengajarkan ilmu agama dalam arti transfer of knowledge. Ini karena pesantren harus jelas memiliki potensi sebagai "lahan" pengembangan ilmu agama. Ketiga, dunia pesantren harus mampu menempatkan dirinya sebagai transformasi, motivator, dan inovator.

Dengan demikian, maka rumusan strategi pesantren dalam menghadapi peradaban modern dapat diklasifikasikan pada (1) memahami landasan dan konsep kebangkitan, (2) merumuskan kembali tujuan pesantren, (3) membenahi sistem pendidikan pesantren, (4) meningkatkan manajemen pesantren, (5) meningkatkan kualitas output pesantren, (6) refungsionalisasi pesantren, (7) membangun mitra kerjasama ke luar, (8) meningkatkan peran pesantren, (9) modernisasi dalam teknologi, informasi dan komunikasi, dan (10) program unggulan di era globalisasi.

44 Nanang Fattah, Landasan Manajemen Pendidikan (Bandung: Remaja Rosdakarya, 2000), Cet. 3, h. 15 
Berdasarkan analisis yang telah dikemukaan tersebut, maka dirumuskan beberapa temuan mengenai masalah penelitian yang terdiri dari:

1. Pandangan pondok pesantren terhadap nilainilai peradaban modern bersifat kognitif reaksioner, artinya penilaian terhadap peradaban modern tersebut disikapi dalam bentuk pewacanaan dan menimbulkan sikap reaktif sehingga melupakan substansi dari nilai-nilai peradaban yang menurut para ahli merupakan suatu keniscayaan, dan pesantren sebagai lembaga pendidikan haruslan meresponnya dalam bentuk counter value, melalui sistem pendidikan dan pembelajaran.

2. Mengenai respon pondok pesantren dalam menghadapi nilai-nilai peradaban modern tergambar melalui penjagaan tradisi pesantren, dan dalam pembahasan tergambar bahwa respon pondok pesantren di Provinsi Bengkulu terhadap nilai-nilai peradaban modern bersifat adaptif, selektif dan asimilatif.

3. Potensi pondok pesantren di Provinsi Bengkulu dapat dilihat dari berbagai aspek, secara umum peneliti gambarkan bahwa potensi mendasar dari pesantren adalah populasi penduduk di Provinsi Bengkulu yang kian hari kian bertambah serta rasio antara penduduk dengan lembaga pendidikan Islam yang menunjukkan bahwa potensi calon santri masih sangat banyak. Selain itu, secara kultural dan ideologis, masyarakat Provinsi Bengkulu masih memiliki fanatisme keberagamaan, sehingga dimungkinkan akan sangat mudah menggaet mereka untuk menyerahkan anaknya kelingkungan pendidikan pesantren, potensi selanjutnya adalah potensi ekonomi, dimana pesantren di Provinsi Bengkulu tumbuh dan berkembang di sentra-sentra ekonomi masyarakat, sehingga dapat menjaga keberlangsungan financialnya melalui pengembangan amal usaha pesantren di berbagai sektor.

4. Strategi pondok pesantren dalam menghadapi nilai- nilai peradaban modern guna menjaga eksistensinya dapat di lihat dari kekuatan, peluang, kelemahan dan ancaman (SWOT), dalam disertasi ini disebutkan bahwa strategi yang dilakukan pondok pesantren di Provinsi Bengkulu adalah dengan cara modernisasi manajemen pengelolalan pendidikan, termasuk mengenai administrasi, organisasi, tenaga pendidik dan kependidikan, supervisi dan evaluasi.

Terlepas dari prospek masa depan pesantren, ada beberapa masalah yang dihadapi pesantren disebabkan keterbatasan kemampuan pengelolanya. Masalah tersebut antara lain ${ }^{45}$ :

1. Sarana dan prasarana penunjang yang terlihat masih kurang memadai. Selama ini, kehidupan pondok pesantren yang penuh kesederhanaan dan kebersahajaannya tampak masih memerlukan tingkat penyadaran dalam melaksanakan pola hidup yang bersih dan sehat yang didorong oleh penataan dan penyediaan sarana dan prasarana yang layak dan memadai.

2. Sumber daya manusia. Sekalipun sumber daya manusia dalam bidang keagamaan tidak dapat diragukan lagi, tetapi dalam rangka meningkatkan eksistensi dan peranan pondok pesantren dalam bidang kehidupan sosial masyarakat, diperlukan perhatian yang serius. Penyediaan dan peningkatan sumber daya manusia dalam bidang manajemen kelembagaan, serta bidang-bidang yang berkaitan dengan kehidupan sosial masyarakat, harus menjadi prioritas pesantren.

3. Manajemen kelembagaan. Manajemen merupakan unsur penting dalam pengelolaan pesantren. Pada saat ini masih terlihat bahwa pesantren dikelola secara tradisional apalagi dalam penguasaan informasi dan teknologi yang masih belum optimal. Hal tersebut dapat dilihat dalam proses pendokumentasian (data base) santri dan alumni pesantren yang masih kurang terstruktur.

4. Kemandirian ekonomi kelembagaan. Kebutuhan keuangan selalu menjadi kendala dalam melakukan aktivitas pesantren, baik yang berkaitan dengan kebutuhan

${ }^{45}$ Muhammad Idris Usman, "Pesantren Sebagai Lembaga Pendidikan Islam," Jurnal IImiah Lembaga Pendidikan Islam Pare-Pare Kediri, 2011), h. 22 
pengembangan pesantren maupun dalam proses aktivitas keseharian pesantren. Tidak sedikit proses pembangunan pesantren berjalan dalam waktu lama yang hanya menunggu sumbangan atau donasi dari pihak luar, bahkan harus melakukan penggalangan dana di pinggir jalan.

5. Kurikulum yang berorientasi life skills santri dan masyarakat. Pesantren masih berkonsentrasi pada peningkatan wawasan dan pengalaman keagamaan santri dan masyarakat. Apabila melihat tantangan kedepan yang semakin berat, peningkatan kapasitas santri dan masyarakat tidak hanya cukup dalam bidang keagamaan semata, tetapi harus ditunjang oleh kemampuan yang bersifat keahlian.

\section{Penutup}

Berdasarkan hasil kajian yang telah dilakukan, maka dapat disimpulkan beberapa hal berikut. Pertama, potensi yang dimiliki oleh pondok pesantren di Provinsi Bengkulu terbagi pada beberapa hal, yaitu potensi masyarakat yang mayoritas muslim, potensi internal dalam bentuk tradisi pesantren yang terdiri dari kiai, santri, pondok, masjid dan kitab kuning yang diharapkan dapat fokus pada pengkajian ilmu-ilmu keislaman yang relevan dengan perdaban modern. Potensi berikutnya adalah potensi pengembangan ilmu pengetahuan dan teknologi berbasis tauhid serta yang terakhir potensi ekonomi melalui pengembangan amal usaha pondok pesantren dari berbagai sektor guna menumbuhkan kemandirian lembaga, kemandirian pengelola dan kemandirian santri dalam menghadapi nilai-nilai peradaban modern. Kedua, Strategi pondok pesantren dalam menghadapi nilainilai peradaban modern guna menjaga eksistensinya dapat dilihat dari kekuatan, peluang, kelemahan dan ancaman (SWOT). Dalam artikel ini disebutkan bahwa strategi yang dilakukan pondok pesantren di Provinsi Bengkulu adalah dengan cara modernisasi manajemen pengelolalan pendidikan, termasuk mengenai administrasi, organisasi, tenaga pendidik dan kependidikan, supervisi dan evaluasi.

\section{Pustaka Acuan}

Abdullah, Suparman Ibrahim (ed.), $M$ a'had 'Aly: Profil Pendidikan Tinggi Pondok Pesantren di Indonesia, Responsible Development International RDI, 2005.

Adib, Khoirul, Kebudayaan Islam dan Perkembangannya, dalam Tim Dosen PAI Universitas Negeri Malang, Aktualisasi Pendidikan Islam: Respons terhadap Problematika Kontemporer, Surabaya: Hilal Pustaka, 2010.

Admodiwiro, Soebagio, Manajemen Pendidikan Indonesia Jakarta: Arda Dizya Jaya, 2000.

Amirsyahruddin, Integrasi Imtaq dan Iptek dalam Pandangan $H$. Abdullah Ahmad, Padang: Syamsa Offset, 1999.

Asiyah, "Tipologi Pendidikan Islam Di Indonesia: Dari Dikotomik Ke Sistematik", Jurnal Insan Cendikia, Volume 4 No 2 Juli-Desember 2014.

Asrohah, Hanun, Pelembagaan Pesantren; Asalusul dan Perkembangan Pesantren di Jawa, Jakarta: Departemen Agama RI Bagian Proyek Peningkatan Informasi Penelitian dan Diklat Keagamaan, 2004.

Attas, Al-, Islam, Religion and Morality, dalam Prolegomena to the Methapgysics of Islam, Malaysia: Istac, tp, 1995.

Bogdan and Biklen, Qualitative Research for Education, Boston Allyn and Bacon, 1992

Bourdieu, Pierre, The Field Of Cultural Production, Polity Press, Cambridge, 1993.

Buchori, Mochtar, Pendidikan Antisipatoris, Yogyakarta: Kanisius, 2001.

Dofier, Zamakhsyari, Tradisi Pesantren: Studi Pandangan Hidup Kiai dan Visinya Mengenai Masa Depan Indonesia, Jakarta: LP3S, 2011, cet-IX.

Efendi, Djohan, Pesantren dan Kampung Peradaban (Sebuah Pengantar), dalam: Hasbi Indra, Pesantren dan Transformasi Sosial: Studi Atas Pemikiran K.H. Abdullah Syafi'ie dalam Bidang Pendidikan Islam, Hasan M. Nur (Ed), Cet. 1, Jakarta: PENAMADANI.

Faruqi, Ismail Raji al-, Atlas Budaya Islam: Menjelajah Khasanah Peradaban Gemilang, Bandung: Mizan, 2001 
Fattah, Nanang, Landasan Manajemen Pendidikan Bandung: Remaja Rosdakarya, 2000, Cet.ke-3.

Hasyim, Abd. Wahid, Ringkasan Disertasi "Pesantren dan Politik" UIN Jakarta: Jakarta, 2007.

http://ditpdpontren.kemenag.go.id/tag/bankindonesia/. Diakses tanggal 25 Desember 2016.

http://ditpdpontren.kemenag.go.id/tag/bankindonesia/. Diakses tanggal 25 Desember 2016.

http://www.uin-alauddin.ac.id/download-09\%20 Dualisme\%2oPendidikan\%2oCenter.pdf. diakses tanggal 2 April 2016.

Ibn Mander, Lisin al-'Arab al-Mulei, Beirut: Daar Al-Jayl, 1988.

Karim, M.Abdul, Sejarah Pemikiran dan Peradaban Islam, Yogyakarta : Pustaka BOOK Publisher, 2009.

KBBI, Kamus Besar Bahas Indonesia. Jakarta: Pusat Bahasa, Departemen Pendidikan Nasional, 2008.

Lewis, Bernard, The Arab in History, New York: Harper \& Row, Publisher, 1967.

Madjid, Nurcholis, Islam: Doktrin dan Peradaban, Jakarta: Paramadina, 2000. Bilik-Bilik Pesantren, Dian Rakyat, Jakarta tt.

Mastuhu, Dinamika Sistem Pendidikan Pesantren; Suatu Kajian Tentang Unsur dan Nilai Sistem Pendidikan Pesantren, Jakarta: INIS, 1994.

Mudji, Sutrisno, Filsafat Kebudayaan-Ihtiar Sebuah Teks, Jakarta: Cetekan Pertama, Hujan Kabisat.

Muhammad, Nabilah Hasan, Fi Tarîkh al-Hadârah al-Islâmiyah, Iskandariyah: Daar al-Ma'rifah, tt.

Munir, "The Continuity and Change of Pesantren Tradition: Study Network Main Pesantren and Alumni Pesantren in Kabupaten OKU Timur, South Sumatra", Jurnal Pendidikan Islam, Volume 5, Number 2, December $2016 / 1438$.

Nasr, Seyyed Hossein \& Smith, Huston, Islam: Religion, History, and Civilization, LahorePakistan: Suhail Academy, 2005.
Piliang, Yasraf Amir, Sebuah Dunia Yang di Lipat; Realitas Kebudayaan Menjelang Millenium Ketiga dan Matinya Postmodernisme, Bandung: Mizan Pustaka, 1998.

Purwanto, Ngalim, Administrasi dan Supervisi Pendidikan Bandung: Remaja Rosdakarya, 1995.

Qashash, Ahmad al-, Nusyû' al-Hadârah al-Islâmiyah, Maktabah Syamilah, al-Ishdar al-Tsani, tt.

Rangkuti, Freddy, Analisis SWOT Membedah Kasus Bisnis, Jakarta: Gramedia, 2008

Shiba'i, Mustafa Husni al-, Khazanah Peradaban Islam, Bandung: CV. Pustaka Setia.

Steenbrink, Karel A, Pesantren, Madrasah, Sekolah Jakarta: LP3ES. 1986

Subhan, Arief, Lembaga Pendidikan Islam di Indonesia Abad 20; Pergumulan Antara Modernitas dan Identitas, Jakarta: Prenada Media Grup, 2012.

Sugiyono, Metode Penelitian Pendidikan, Bandung: Alfa Beta, 2012, cet. Xv.

Suteja, "Pola Pemikiran Kaum Santri:Mengaca Budaya Wali Jawa", dalam Pesantren Masa Depan: Wacana Pemberdayaan dan Transformasi Pesantren,, ed. Marzuki Wahid. et.all. Bandung: Pustaka Hidayah, 1999.

Sutrisno, Mudji, Filsafat Kebudayaan-Ihtiar Sebuah Teks, Jakarta: Cetekan Pertama, Hujan Kabisat

Toynbee, Arnol, The Disintegrations of Civilization dalam Theories of Society, New York, The Free Press, 1965.

Usman, Muhammad Idris, "Pesantren Sebagai Lembaga Pendidikan Islam," Jurnal IImiah Lembaga Pendidikan Islam Pare-Pare Kediri, 2011.

Wahab, Abdul, “Dualisme Pendidikan di Indonesia”, Jurnal Lentera Pendidikan, Vol. 16 No. 2 DESEMBER 2013.

Wahid, Abdurrahman, Standarisasi Sarana Ilmiah di Pondok Pesantren, dalam Menggerakkan Tradisi, Yogyakarta; LKiS, 2010.

, Universalisme Islam dan Kosmopolitanisme Peradaban Islam dalam Nur Kholis Madjid, Islam Universal, Yogyakarta: Pustaka Pelajar, 2007. 
Wora, Emmanuel, Perenialisme, Kritik atas Modernisme dan Postmodernisme, Yogyakarta: Kanisius, 2006.

Yatim, Badri, Sejarah Peradaban Islam, Jakarta: PT. Raja Grafinda Persada, 1999.
Yunus, Mahmud, Sejarah Pendidikan Islam di Indonesia, Jakarta: Mutiara Sumber Widya, 1995, cet. ke-5.

Zeimek, Pesantren dan perubahan sosial. Jakarta: P3M, 1986. 